\title{
Interjú prof. dr. Kovács László dandártábornokkal, a Magyar Honvédség Parancsnokságának kibervédelmi szemlélőjével
}

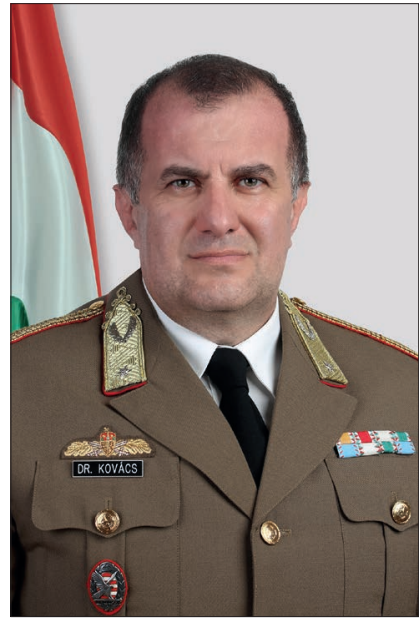

\begin{abstract}
- Milyen lehetőségeket lát Tábornok úr abban, hogy a NATO haderőnemi szintre fejlesztette az úrerőket, illetve a kiberhadviselést? Milyen technológiai, kutatás-fejlesztési következményei lesznek ennek a Magyar Honvédségre nézve?
\end{abstract}

- A Szövetség 2016-ban a NATO varsói csúcsértekezletén döntött arról, hogy a kiberteret is múveleti térré nyilvánítja. Ezzel párhuzamosan a tagállamok olyan kibervédelmi képességfejlesztésekről döntöttek, amelyek megfelelő válaszokat nyújthatnak az új múveleti térben jelentkező kihívások kezelésére. Ezek a fejlesztések komoly kutatás-fejlesztési tevékenységet igényelnek, mert bár a civil informatikai és kibervédelmi piacról sok eszköz és megoldás beszerezhető, mégis vannak olyan védelmi - esetünkben honvédelmi - specifikumok, amelyek a terület jellemzői miatt ezt a $\mathrm{K}+\mathrm{F}$ tevékenységet igénylik. Természetesen ebbe a programba be kell vonni az akadémiai szférát és a civil fejlesztések tapasztalatait is. Ennek a kutatás-fejlesztésnek az egyik motorja a Magyar Honvédségben a Modernizációs Intézet, amely a konkrét kutatásokan kívül komoly koordinációs szerepet is betölt a kutatási igények és a kutatási kapacitások egymáshoz történő közelítésében.

Mindezek mellett a Kibervédelmi Szemlélőség egyik kiemelt feladata annak a kutatás-fejlesztési képességnek a kialakítása, amelynek segítségével a Magyar Honvédség speciális kibervédelmi és kiberműveleti képességei kialakíthatóak. Természetesen ezt prioritással kezeljük, amely érdekében egy olyan $\mathrm{K}+\mathrm{F}$ csapatot hozunk létre, amelynek tagjai a kibervédelmi és kiberműveleti szakemberek mel- lett, azokkal együtt dolgozva közvetlenül végeznek fejlesztési munkát. Emellett közvetett módon, például a már említett MH Modernizációs Intézeten keresztül elősegítik, hogy a hazai akadémiai szférához, valamint az újjáéledő hazai haditechnikai vállalatokhoz eljussanak az igényeink, illetve azok megoldásra is kerüljenek.

Ahogy a kibertér müveleti térré vált, úgy ez igaz az ürre is. 2019-ben a NATO az űrt is műveleti térré nyilvánította, amely egyenes következménye annak, hogy számos ország hatalmas űripari, és űr-hadiipari fejlesztésekbe kezdett. Néhány országban máris megmutatkoznak az első eredmények. Nyilvánvaló, hogy ezeket a fejleményeket nekünk is követnünk kell, és egy egységes hazai űrstratégia mellett folytatnunk kell azokat a kutatás-fejlesztési tevékenységeket, amelyek eredményei már hazánk esetében is látszanak. Meg kell vizsgálnunk, hogy e kutatások közül a Magyar Honvédség mely eredményeket, milyen feladatokra tud használni vagy hasznosítani. Itt elsősorban olyan felhasználási területek jelentkezhetnek, mint például a kommunikáció, az adatátvitel, vagy a távérzékelés.

- Tábornok úr, Ön a Magyar Honvédség Parancsnoksága kibervédelmi szemlélői beosztását megelőzően az NKE professzoraként dolgozott. Szakmai pályafutásáról mondana néhány szót? Melyek a személyes tervei szakmai és tudományos területen?

- 1991-ben végeztem az akkori Bolyai János Katonai Műszaki Főiskolán rádióelektronikai, vagy, ahogy ma ezt a területet hívjuk elektronikai hadviselési tisztként. Ez a terület azóta is nagyon közel áll hozzám, amely talán nem vé-
ÖSSZEFOGLALÁS: 2016-ban a NAT0 a kiberteret is múveleti térré nyilvánította. Ennek övetkeztében a Magyar Honvédség a Zrínyi 2026 haderőfejlesztés program során kialakítja magas szintü kibervédelmi képességét. 2019 júniusában megnyiltt a Magyar Honvédség Kiber Képzési Központja. Létrejött a Mesterséges Intelligencia Koalíció, amelynek munkájában a Magyar Honvédség, illetve a honvédelmi ágazat is részt vesz. Kinevezték a Magyar Honvédség Parancsnokságának kibervédelmi szemlélőjét, prof. dr. Kovács László dandártábornokot. Vele készített interjút a Haditechnika tudományos folyóirat szerkesztősége.

KULCSSZAVAK: Zrínyi 2026 haderőfejlesztési program, kibervédelem, Magyar Honvédség Kiber Képzési Központ
ABSTRACT: In 2016, NAT0 also declared cyberspace an operational space. As a result, the Hungarian Defence Forces will develop a high-level cyber defence capability during the Zrínyi 2026 Defence and Armed Forces Development Program. In June 2019, the Cyber Training Centre of the Hungarian Defence Forces opened. The Artificial Intelligence Coalition has been established, in the work of which the Hungarian Defence Forces and the defence sector also participate. Brigadier General Prof. dr. László Kovács was appointed as the Cyber Defence Observer of the Combat Command of the Hungarian Defence Forces. He was interviewed by the editorial board of the scientific journal Haditechnika.

KEY WORDS: Zrínyi 2026 Defence and Armed Forces Development Program, cyber defence, Cyber Training Centre of the Hungarian Defence Forces

Mérnök alezredes PhD, NKE Hadtudományi és Honvédtiszképző Kar, Haditechnikai Tanszék. MHTT Légierő Szakosztály elnök.

ORCID: 0000-0001-8457-5044

** ORCID: 0000-0002-3902-0151 
letlen, hiszen a kibervédelem nagyon sok hasonlóságot mutat az elektronikai hadviseléssel, sőt a két terület technikai eszközeiben és azok eljárásaiban bizonyos konvergencia figyelhető meg.

Néhány év csapatszolgálat után következett az egyetem, amely nagy szerepet játszott a tudományos pályára terelésemben. Az egyetemen egy olyan fantasztikus tudományos közegbe kerültem, amely nem csak inspirált, de nagyban meg is változtatta az addigi gondolkodásomat. Az egyetemi évek alatt fokozatosan a kiberhadviselés felé fordultam, és bár a 2004-ben megvédett doktori értekezésem témája csak érintőlegesen kapcsolódott ezzel a területtel, az azt követő időszak azonban olyan tudományos kutatásokat hozott a számomra, amelyek már a kiberhadviselést jelentették. Ezt követően az egyetemi katedrát választva az oktatás mellett számos kutatás-fejlesztési projektben vehettem részt, amelyek a technikai ismeretek mellett sok kutatás-szervezési tapasztalatot is adtak. 2010-ben a köztársasági elnök kinevezett egyetemi tanárnak, és akkor úgy gondoltam, hogy bár meglehetősen fiatal vagyok, de ez a pályafutásom csúcsa. Természetesen az ilyen kijelentéseket az élet sokszor cáfolja. Nem volt másként ez esetemben sem. A kiberbiztonság tudatosítása mellett, a kiberhadviselés területén igyekeztem kollégáimmal és doktorandusz hallgatóimmal is olyan eredményeket elérni, amelyek a gyakorlatban is alkalmazhatóak. Talán ennek is köszönhető, hogy az új szervezetként felálló Magyar Honvédség Parancsnoksága tervezési és szervezési munkái során azt a megtisztelő feladatot kaptam, hogy a gyakorlatban is bizonyítsam az elméleti kutatásaink életképességét. Az MHP megalakításakor felkérést kaptam a kibervédelmi szemlélőség vezetésére.

Természetesen a tudományos kutató- és az egyetemi oktatómunkát sem hagytam abba, hiszen bár lényegesen kevesebb időben, de továbbra is tanítok az egyetemen, vezetem a doktorandusz hallgatóimat, illetve kiberbiztonsági stratégiákat elemző értekezésemmel pályázatot nyújtottam be a Magyar Tudományos Akadémia doktora címre.

- Mi a véleménye a Zrínyi 2026 haderőfejlesztési program során a kibervédelem fejlesztésével kapcsolatos lehetőségekről?

- Úgy gondolom, hogy valóban történelmi lehetőséget kaptunk, hiszen az elmúlt 40 évben nem volt ilyen nagy és átfogó program a haderő teljes átalakítására. Véleményem szerint a Zrínyi 2026 reális lehetőséget teremt egy korszerü és ütőképes haderő kialakítására.

Ez azonban nemcsak lehetőség, hanem felelősség is. Ez igaz a kibervédelmi és kiberműveleti képességek kialakítására is. Ezzel a programmal meg kell teremtenünk, hogy a kiberműveleti képességek hozzá tudjanak járulni a kinetikus képességek valódi és hatékony támogatásához, és ezzel párhuzamosan képesek legyenek önálló kiberműveletek végrehajtására, természetesen a megfelelő nemzetközi és hazai jogszabályi, valamint doktrinális keretek között. Ez önmagában is komplex feladat, hiszen a haditechnikai kutatás-fejlesztés mellett többek között a kibertérben történő műveletekhez szükséges jogszabályi háttér kialakítását is el kell végezni, amely ugyanúgy fontos, mint a különböző haderőnemek támogatásához szükséges kiberműveleti eljárásrend kialakítása.

Ahogy egyik kollégám fogalmazott néhány hónappal ezelőtt: „,a feladat nem kisebb, mint egy új haderőnem felállítása". Ez a kiber-haderőnem, amely bár ma még valóban kicsit furcsán hangzik, de olyan komoly feladatokkal kell szembenéznie az ebben a haderőnemben dolgozó szakembereknek, amelyek sok esetben ma még nem is ismertek. Ehhez filozófiai és gondolkodásbeli váltásra is szükség van. A kibertérben már a kutatás-fejlesztés is egy eddig ismeretlen attitűdöt és gondolkodást igényel mind vezetőktől, mind a technikai szakemberektől.

- Mi a most létrehozott Kibervédelmi Akadémia feladata? Hogyan kapcsolódik ez a Zrínyi 2026 haderőfejlesztési programhoz?

- A Magyar Honvédség Kiber Képzési Központja, vagy ahogy röviden hívjuk, a Kiberakadémia célja kiberszakemberek képzése és továbbképzése. Ehhez ki kellett alakítanunk egy 21. századi színvonalú fizikai és informatikai infrastruktúrát. A Kiberakadémia informatikai infrastruktúrája mesterséges intelligencia ( a továbbiakban: MI) támogatással úgy nyújt szimulációs, és egyben gyakorlási lehetőséget a szakemberek számára, hogy az rugalmasan konfigurálható, változtatható és akár személyre is szabható. Ilyen gyakorlati hely eddig csak részben volt elérhető hazánkban.

A Kiberakadémia másik nagy feladata a kiberbiztonsági tudatosság növelése. Ezt a szemléletet a haderő vezetőitől kezdve, az információkat kezelő ügykezelőkön keresztül a harcoló katonáig, mindenki számára szeretnénk átadni, hiszen számítógépet, vagy okostelefont mindenki használ, így mindenki kapcsolatba is kerül a kibertérrel. Ebből következően a legelemibb kiberbiztonsági ismeretekre mindenkinek szüksége van.

A Kiberakadémia ezenkívül kutatás-fejlesztési potenciállal is rendelkezik, hiszen az az informatikai környezet, amelyet a képzésre használunk ezt is lehetővé teszi.

- Hogyan múködik együtt a kibervédelmi szakterület az akadémiai, kutatóintézeti és felsőoktatási szektorral?

- Ezen a szakterületen elengedhetetlen az együttműködés a különböző szereplők között. A terület olyan gyorsan változik, illetve olyan gyorsan jelennek meg újabb és újabb kihívások, hogy azokra megoldást csak közös gondolkodással és együttműködéssel tudunk találni. A legegyszerübben talán ezt úgy lehet kifejezni, hogy a szakterület a megoldásra váró igényeit és problémáit megfogalmazza, azokat az akadémiai, illetve a kutatói szféra számára átadja, akik pedig ezeket az igényeket figyelembe véve alakítják ki kutatásaikat. Ezek a kutatások a kiber szakterületen mind hazai, mind nemzetközi együttműködéseket egyaránt igényelnek. A felsőoktatási intézmények bevonása ebbe a munkába szintén elengedhetetlen, hiszen a terület tudás alapú, amelyhez a tudás sok esetben az egyetemeken, illetve az azok mellett működő kutatóintézetekben van jelen. A hallgatók bevonása szintén hatalmas előnnyel jár, hiszen az a hallgató, aki egyegy, a szakterület által megfogalmazott probléma megoldásán dolgozik, a diplomája átvétele után lehet, hogy éppen ezt a megoldást használja majd a munkája során.

- Milyen mélységú az Ön szakterületén a doktoranduszok és tudományos fokozattal rendelkezők kutatási- és publikációs tevékenysége? Milyen a kapcsolatuk a tudományos szaksajtóval?

- Az elmúlt években ugrásszerűen nőtt a területen dolgozó kutatók száma, amely igaz a doktorandusz hallgatókra is. Emellett szintén örömteli, hogy évről évre nő az olyan tudományos publikációk száma is, amelyek a kibertér egyes szegmenseivel, egyes kihívásaival foglalkoznak. Véleményem szerint a tudományos eredmények publikálásához elegendő mennyiségű tudományos fórum áll rendelkezésre. Az említett tudományos lapok sok esetben egyetemekhez köthetőek. Ugyanakkor ezeknek - az elsősorban tudományos folyóiratokat jelentő - fórumoknak a nemzetközi láthatósága, azaz a nemzetközi elismertsége javítandó.

A nemzetközi láthatóság kialakítására jó példa a kibertéri tudományos tevékenység egyik meghatározó intézménye, a NATO Kibervédelmi Kiválósági Központja, amely 
Tallinnban müködik, és amely intézmény nagyon sok lehetőséget ad a nemzetközi kibertéri kutatási eredmények publikálására. Az ilyen, és az ehhez hasonló publikálási lehetőségek feltárása kiemelten fontos ahhoz, hogy egyrészt a magyar kutatók eredményeit megismertessék a nemzetközi szakmai és tudományos közösséggel, másrészt pedig ezeken keresztül nemzetközi kutatási partnereket és kapcsolatokat találjanak.

- Milyen jellegú tudományos konferenciákat szerveztek eddig? Ezek között volt-e nemzetközi? E téren mik a jövőbeni terveik?

- Számos tudományos konferenciát szerveztünk az elmúlt években, amelyből talán a Robothadviselés tudományos konferencia az egyik legismertebb. A közel 20 éves konferencia-sorozat az elmúlt 10 évben kiegészült a kiberbiztonsági és a kiberhadviselési témákkal, amelyek évrőlévre, immár önálló szekciókban alkalmat adtak a kutatási eredmények, és sok esetben a kutatás-fejlesztés-innováció eredményeként létrejött eszközök és megoldások bemutatására. Ezt a konferenciasorozatot folytatni és mind résztvevői körében, mind tematikájában szélesíteni, bővíteni szeretnénk.

- Hogyan látja a jövő korszerü haderőinek kulcsképességeit? Inkább a méret és az erőforrások fontosak, vagy a korszerú haditechnikához való viszonyulás?

- Ebben a kérdésben egy már jól ismert paradigmaváltás zajlott az elmúlt évtizedekben, hiszen a nehézfegyverzetű tömeghadseregeket felváltották a jóval mozgékonyabb, kisebb létszámú, de ütőképesebb, vagy annak gondolt hadseregek. Ugyanakkor a 2010-es évek biztonságpolitikai változásai, kiegészülve az új kihívásokkal, amelyek többek között éppen a kibertérben jelentek meg, mindezeket ismét felülírták.

Amennyiben a haditechnikára szűkítjük a választ, akkor kijelenthetjük, hogy az olyan hagyományos szárazföldi nehézfegyverekre, mint a harckocsi, vagy a tüzéreszközök, de akár a légierő esetében a vadászrepülők, továbbra is szükség van. Véleményem szerint a közeljövő háborúit még mindig a fizikai dimenziókban fogják megvívni, de egyre inkább elengedhetetlen lesz, hogy az ezekben a dimenziókban alkalmazott haditechnikai eszközök hatékonysága a lehető legnagyobb legyen. Ehhez az egyik megoldás a számítógép-alapú vezetési rendszerek alkalmazása, amely vezetési rendszerbe a harckocsit a saját számítógépével kapcsoljuk be. Ez a számítógép - illetve az azon futó szoftverek - nem csak a kommunikációt teszik lehetővé, de abszolút módon lerövidítik a döntéstől a tűzkiváltásig, vagy bármilyen feladatvégrehajtásig szükséges időt. A jövő, sőt a jelen haditechnikája tehát számítógép és számítógép-hálózati alapú fegyverrendszereket jelent. Mindezekhez szorosan kapcsolódik a felderítés, az adatok feldolgozása, illetve a logisztika.

Ez a technikai fejlettség ugyanakkor komoly kihívást is jelent, hiszen a számítógépek hálózatba kapcsolásával az adott haditechnikai eszköz, ha korlátozott mértékben is, de a kibertér részévé válik. Annak kibervédelmét tehát meg kell teremteni. A másik oldalról azonban lehetőség is, hiszen ha a szembenálló fél is ilyen rendszereket használ, akkor annak gyenge vagy sérülékeny pontjai kiberműveletekkel hatékonyan támadhatóvá, kihasználhatóvá válnak.

Mindezek mellett a jövő hadereje egyre inkább a robotokra fog támaszkodni, amelyek esetében a fent említett tényezők még hangsúlyosabbak lesznek. Ebből következően a jövőre irányuló haditechnikai kutatások nem nélkülözhetik a kibervédelmi kérdéseket, legyen szó szárazföldi, vagy akár légierőben alkalmazható eszközökről.
Ahogy korábban utaltam rá, a kiberhadviselés önmaga is figyelemre méltó potenciállal fog rendelkezni, hiszen az egyes kiberfegyverek alkalmazása elképzelhető lesz már nemcsak katonai, hanem bizony civil célpontok ellen is. A határ a háború, a hibrid, illetve a békében végzett műveletek között elmosódhat, és például a kritikus infrastruktúrák elleni kibertámadások jóval hatékonyabbak - esetleg jóval olcsóbbak is - lesznek, mint a fizikai dimenzióban kivitelezett támadások. Ez előrevetíti a hadviselés és a katonai műveletek radikális újraértelmezését is. Bár ahogy említettem, véleményem szerint a következő 20-30 évben is a fizikai térben zajlanak majd a háborúk, de ezek mellett egyre nagyobb szerepet kapnak a fejlett informatikai és elektronikai, illetve akár a mesterséges intelligencia által vezérelt kiber-fizikai, majd kibertámadások együttesei is.

- Hogyan látja a mesterséges intelligencia alkalmazásának térnyerését a korszerű hadviselésben? Mi foglalkozunk ezekkel a területekkel hazai szinten?

- A mesterséges intelligencia térnyerésének valóban tanúi vagyunk, amely már a hétköznapjainkban is számtalan területen jelen van. Ez alól a hadviselés sem kivétel. Úgy gondolom, hogy a drónok és a szárazföldi robotok területén már eddig is hatalmas fejlődésen ment keresztül a mesterséges intelligencia. Vannak azonban olyan területek, amelyek nem ennyire látványosak, de - a mesterséges intelligenciának köszönhetően - ezeken mégis valódi áttörés született az elmúlt két-három évben. Az egyik ilyen szakterület a felderítés, hiszen a felderítés egyik legnagyobb problémájára, nevezetesen a hatalmas adatmennyiség feldolgozására, az MI nagyon hatékonyan alkalmazható.

Hazai szinten elmondható, hogy a kormányzati támogatással létrejött Mesterséges Intelligencia Koalíció, amelynek munkájában a Magyar Honvédség, illetve a honvédelmi ágazat is részt vesz, hatalmas munkát végzett az elmúlt időszakban. Ennek köszönhetően kidolgozásra került egy hazai mesterséges intelligencia stratégia, amely mentén nemcsak a hazai Ml kutatás-fejlesztés, hanem az azok eredményeként megjelenő megoldások is valódi előnyöket fognak jelenteni hazánknak.

- Hogyan látja a katonai-múszaki tudományterület jövőjét, különös tekintettel a kibervédelem területén folytatott tudományos kutatásokra?

- Úgy gondolom, hogy valódi tudományos kutatások nélkül nem lehetséges kutatás-fejlesztés, és nem lehetséges valódi innováció sem. Ez természetesen igaz a kibervédelem területére is. Mindezek azonban azt is feltételezik, hogy ezeket a tudományos kutatásokat és magát a kutatás-fejlesztés-innováció együttesét csak az említett szakterületi, akadémiai, felsőoktatási, valamint gazdasági szféra együttműködésével lehet eredményesen megvalósítani. A jövőben a katonai műszaki tudományok felértékelődését várom, mert a jövő haditechnikája meghatározó lesz a biztonság területén.

Mindez azt is magával hozza majd, hogy a katonai müszaki tudományok és a műszaki tudományterület többi tudományága, vagy akár a klasszikus hadtudományi kutatások között egyre nehezebb lesz éles határt húzni. A különböző tudományterületek és a különböző tudományágak, illetve az azokon folyó kutatások eredményei szinergiájának leszünk tanúi a jövőben.

A világ, és benne a kibertér egyre komplexebbé válik. Egy-egy biztonsági kihívás számos területre van közvetlen, vagy közvetett hatással. Így a kihívások már ma is, de a jövőben még inkább komplex válaszokat igényelnek, legyen szó a haditechnikáról vagy akár a kibertérről. 